\title{
JERZY LITWIN
}

Narodowe Muzeum Morskie w Gdańsku

E-Mail: j.litwin@nmm.pl

\section{PIASKARZE NA WIŚLE I ICH ŁODZIE (XIX-XX WIEK)}

Jednym z zajęć ludności nadrzecznej, szczególnie popularnym w XIX i pierwszych dekadach XX wieku, było piaskarstwo, czyli wydobywanie żwiru lub piasku z dna rzeki. Tę ciężką pracę udokumentował w 1887 roku na jednym z obrazów olejnych Aleksander Gierymski (1850-1901). Artysta przedstawił na nim finalny etap pracy wykonywanej przez piaskarzy i ich pomocników: wyładowywanie żwiru z łodzi na wysokie nabrzeże w Warszawie ${ }^{1}$. Piaskarstwo było wykonywane regionalnie, gdyż pożądane kruszywa nie zawsze występowały w dużych ilościach. Nie w każdej rzece (lub nie na wszystkich jej odcinkach) występowały złoża żwiru, ważnego materiału budowlanego. Oprócz żwiru wydobywano w tym czasie również piasek, który odkładał się (zwłaszcza po wiosennych wylewach), na tworzących się w nurcie rzeki oraz utrudniających żeglugę łachach i przemiałach. O ile nie różnił się sposób pobierania żwiru lub piasku z dna rzeki, to łodzie stosowane do tego celu w XIX i XX wieku miały rozmaite formy, różniły się kształtami kadłubów - nawet nad Wisłą, na jej różnych odcinkach.

Wiślanemu piaskarstwu w pierwszej połowie XX wieku, z ośrodkiem pomiędzy Czerwińskiem i Wyszogrodem, dużo uwagi poświecił ostatnio Adam Reszka. W jego opracowaniu pod tytułem Wiślane statki $i$ techniki nawigacyjne od XVI do XX wieku czytamy: „Łapanie żwiru - czyli wydobywanie, odbywało się klasycznym sposobem przy użyciu kaszorów,

1 Obraz Aleksandra Gierymskiego Piaskarze znajduje się w zbiorach Muzeum Narodowego w Warszawie i jest eksponowany na stałej wystawie poświeconej malarstwu polskiemu. URL: https://pl.wikipedia.org/wiki/Piaskarze (dostęp 15.05.2019). 
czyli czerpaków ze stalowych prętów i płaskowników oplecionych drutem, osadzonych na sosnowych drągach o dł. $3 \div 4 \mathrm{~m}$. Metoda ta stosowana powszechnie od dawna, wymagała znalezienia grzempy z odpowiednimi pokładami żwiru, zalegającymi na niewielkiej głębokości”. W publikacji tej został również przedstawiony aspekt ekonomiczny piaskarstwa w latach 1937-1939. Ceny żwiru kształtowały się wówczas na poziomie od 11 do 20 zł za $1 \mathrm{~m}^{3}$, zależne były od podaży oraz jakości granulatu. Żwir „pospółkowaty” (wymieszany z piaskiem) był tańszy, a „rafowy”, o równym granulacie, uzyskiwał najwyższą cenę. Skupujący żwir odbiorcy najlepiej płacili stałym, znajomym dostawcom, toteż armatorzy batów starali się o względy licznych przedsiębiorców, którzy zajmowali się zresztą również wyładunkiem². Wzrost zapotrzebowania na żwir $\mathrm{w}$ regionie warszawskim na przełomie XIX i XX spowodował znaczący wzrost rozmiarów łodzi używanych do tego celu. Już nie zadawalano się łodygami (długie, wąskie łodzie zbijane z kilku desek). Do wybierania żwiru zaczęto stosować znacznie większe łodzie, baty. Ich konstrukcję znamy z ilustracji oraz opisów: kadłuby miały od około 10 do 28 metrów długości, ładowność wynosiła od 10 do $30 \mathrm{~m}^{3}$ żwiru. Najczęściej używano łodzi o długości 25 metrów, mieszczących 18 $\mathrm{m}^{3}$ żwiru, której jeden metr sześcienny ważył około $1800 \mathrm{~kg}^{3}$.

O rozmiarach piaskarstwa w okresie II Rzeczypospolitej świadczy liczba łodzi wykorzystywanych do tego celu. Na podwarszawskim odcinku Wisły (pomiędzy Nowym Dworem Mazowieckim a Dobrzykowem pod Płockiem) w 1938 roku eksploatowano ponad 130 batów, na których pracowało ponad 350 osób (nie licząc osób „łapiących” żwir łodygami, czyli małymi „baciakami” ${ }^{4}$. Takie właśnie łodzie udokumentował na wspomnianym wyżej obrazie Gierymski. Były one stosunkowo małe, identyfikować je można jako łodygi będące typem dużej łodzi konstruowanej w XIX i w początkach XX wieku nad środkową Wisłą, używanej również do rybołówstwa ${ }^{5}$. Przed 1939 rokiem część piaskarzy zatrudnionych była w spółdzielniach i w firmach prywatnych, pozostali czerpali żwir w ramach indywidualnych przedsięwzięć. Jednym z najbardziej znanych było Przedsiębiorstwo Wydo-

2 A. W. Reszka; Wiślane statki i techniki nawigacyjne od XVI do XX wieku, (2012), pp. 75-93.

3 Ibidem, p. 89.

4 Ibidem, pp. 89-90.

5 B. Ślaski, Rybołówstwo i rybołówce na Wiśle dawniej i dziś, (1917), p. 25. 
bycia Żwiru i Piasku B. Matraszek, wydobywające te kruszywa w okolicach Warszawy w latach 1884-1948, gdzie miał też swoją siedzibę Związek Przemysłu Wiślanego.

Jak wyglądały ówczesne baty piaskarskie? Ich fotografie ukazywały się niekiedy w gazetach, na łamach których relacjonowano organizowane okazjonalnie przez Związek Przemysłu Wiślanego regaty batów wiślanych, będące ciekawym widowiskiem i tym samym dużą atrakcją dla mieszkańców Warszawy. Konstrukcje te były używane jeszcze po drugiej wojnie światowej w odbudowywanej Warszawie. W związku ze wzrostem popytu na kruszywa budowlane w okresie powojennym (szczególnie żwir) zaczęto dość szybko wprowadzać w proces pozyskiwania tego materiału najnowsze zdobycze techniczne. W latach 50. zaczęto stosować mechaniczny, znacznie tańszy, sposób wydobywania tego materiału z koryt rzek: za pomocą koparek na pontonach. Spowodowało to stopniowy zanik piaskarstwa. Ostatnim przedsiębiorcą eksplorującym ręcznie dno Wisły był Roman Lemański z Warszawy (do roku 1982) ${ }^{6}$. Posiadał on dwa baty. Jednego używał do wydobycia wyłącznie piasku lub pospółki. Drugi wysyłał na żaglach w górę Wisły do ujścia rzeki Świder (490 km), w celu „łapania” wysokogatunkowego żwiru „rafowego” o równym granulacie, za który bardzo dobrze płacono?

\section{BAT PIASKARSKI}

W języku polskim określenie bat i bacik jako nazwa małego statku lub dużej łodzi występuje już w latach 70. XVI wieku' ${ }^{8}$. Weneccy konstruktorzy okrętów - Domenico Zaviazelo i Jakub Salvadore, którzy w 1570 roku przybyli do Polski, aby podjąć budowę galeonu dla króla Zygmunta Augusta, zbudowali ponadto dwie mniejsze jednostki - fregatę i bat ${ }^{9}$. Całość prac realizowanych w Elblągu nadzorował i rozliczał Jan Bąkowski, powołany w tym celu przez Komisję Morską ${ }^{10}$. Sporządzona przez niego dokumentacja

\footnotetext{
6 Reszka, Wiślane statki, p. 93.

7 Ibidem, p. 93.

8 E. Łuczyński, Staropolskie słownictwo związane z żeglugą. XV i XVI wiek, (1986),
} p. 201.

9 M. Boczar, Galeona Zygmunta Augusta. Próba rekonstrukcji, (1973), pp. 35-37.

10 Ibidem, pp. 36-37. 
wydatków poniesionych na budowę okrętu dotyczy również konstruowania fregaty i bata, które budowali sami wenecjanie ${ }^{11}$. Można przypuszczać, że bat był przeznaczony jako wyposażenie pomocnicze dla galeonu. Wygląd tej łodzi musiał być znany mieszkańcom Elbląga, natomiast fregata miała nieznany tu wygląd, dlatego odpowiedzialny za realizację całego kontraktu Jan Bąkowski wysłał ją do Pucka, bo tam miała być ta jednostka lepiej chroniona ${ }^{12}$.

Problematyce łodzi zwanej batem używanej do piaskarstwa dużo uwagi poświęcił Adam Reszka. Jak stwierdził, słowo „bat” w odniesieniu do konstrukcji pływającej pojawiało się już w starych dokumentach dotyczących spławu, na oznaczenie statku do transportu towarów w ruchu lokalnym i prac pomocniczych, np. odlichtowywania lub przewozów międzybrzegowych $^{13}$. Uważam, że do końca XVIII wieku bat nosił ożaglowanie rejowe, gdyż tylko takie stosowano do tego czasu na Wiśle. W kolejnym stuleciu, pod wpływem obserwacji statków odrzańskich wpływających Kanałem Bydgoskim na Wisłę, w krótkim czasie upowszechniło się zastosowane w nich żagle rozprzowe. W 1916 roku Bolesław Ślaski omawiając typy statków z przełomu XIX i XX wieku stwierdził, że „na małych statkach wiślanych pływają sami „właściciele małych a chodnych statków (kóz i batów), których do szyprów już nikt nie zalicza. Ci mogliby wyżyć jedynie ze spławu towarów, powierzanych im dość rzadko; zmuszeni są przeto imać rozmaitego zarobku, jaki może im dać rzeka, a więc: rybaczyć, dobywać kamienie lub piasek z łona rzeki i t.p. Nie mieszkają oni na statkach, lecz na lądzie, gdyż nie przedsiębiorą nawet odleglejszych wypraw wodnych, a do pomocy przy pławaczce używają zwyczajnych wyrobników, z wodą i pracą na statkach trochę obytych"14.

Adam Reszka przedstawił w swojej publikacji o statkach wiślanych bat z okolic Czerwińska. Swoim kształtem i cechami konstrukcyjnymi przypominał on tradycyjnie budowane nad Wisłą - na pewno od XV do XVIII wieku - statki spławowe. Był w jakimś stopniu miniaturowym wariantem szkuty lub dubasa. Różnił się od nich jedynie ostro zakończonym, niskim klocem dziobu. Miał natomiast, tak jak i one, płaską, pawężową rufę. Ogra-

\footnotetext{
11 A. Kleczkowski, Rejestr budowy galeony. Zabytek $z$ r. 1572., (1915), pp. 65-67.

12 Ibidem, p. 66.

13 Reszka, Wiślane statki, p. 75.

14 B. Ślaski, Spław i spławnicy na Wiśle, (1916), p. 26.
} 
niczała ona od tyłu pomieszczenie mieszkalne (buda), które było w okresie sezonu nawigacyjnego miejscem do wypoczynku nocnego załogi. Dno - jak wszystkich statków rzecznych - było płaskie; z przodu podgięte mocniej $\mathrm{ku}$ górze, $\mathrm{z}$ tyłu mniej ${ }^{15}$. Budowę tego typu łodzi prowadzono podobnie, jak w wypadku innych jednostek nad Wisłą. Rozpoczynano pracę od zmontowania płyty dna z odpowiedniej grubości klepek usztywnianych poprzecznie dennikami (zole), z podcięciami (szparlochami) umożliwiającymi w czasie eksploatacji bata spływanie wody zęzowej do najniżej położonej grotyny. Elementy te spajano drewnianymi kołkami. Już w tej fazie budowy uszczelniano styki klepek. Następnie w części rufowej ustawiano pawęż, zwaną nad Wisłą lustrem. Burty montowano z kilku pasów klepek sosnowych (bretów) układanych na zakładkę i zbijanych żelaznymi gwoździami. Do formowania pochylenia burt często używano szablonu, wzorca wykonanego z kilku zbitych ze sobą desek. Pierwszy pas poszycia burtowego stanowiły bale (klepki) - brony. Były one odpowiednio kształtowane i wyginane, a dolne krawędzie bron wystawały na około $7 \mathrm{~cm}$ poniżej spodu dna. Następnie kładziono drugi pas bali burtowych, dylę. Podobnie jak dwa pierwsze, zakładano pas trzeci, średnicę (wasserłata), i czwarty, wiatrówkę (windłata). Przy średniej długości bata około $25 \mathrm{~m}$, szerokość kadłuba w miejscu największego rozgięcia burt wynosiła $4 \mathrm{~m}$. Grubość bretów była różna i wynosiła w dnie $50 \mathrm{~mm}$; a brona i średnica miały grubość $40 \mathrm{~mm}$, podczas gdy wiatrówka miała aż 3 cale $^{16}$. Bale (klepki) poszycia burtowego były układane na zakładkę i zbijane bratnalami, gwoździami z płaskimi łbami specjalnie odkuwanymi przez kowala. W końcowej fazie montażu kadłuba wstawiano w części dziobowej, w miejscu zbiegu wszystkich klepek dna i burt, starannie wyprofilowany klocek dębowy tworzący dziób (sztaba, tak samo nazywano masywną dziobnicę w szkucie i innych typach statków). Na czwarty, ostatni w burcie bret poszycia będący mocnicą kadłuba, nabijano dodatkową deskę osłaniającą (odbojową) klamburt, a także na ich górną krawędź listwę (opaskę). Elementy te ulegały uszkodzeniom, zwłaszcza opaska zdzierała się podczas opierania na niej tyczek z kaszorami podczas „łapania” żwiru. W miarę zużycia opaska i klamburt były wymieniane,

15 Reszka, Wiślane statki, pp. 75-93. Pracownicy Narodowego Muzeum Morskiego w Gdańsku podczas prac w terenie również zebrali sporo informacji o technice budowy batów i ich wyposażeniu, por. J. Litwin, Polskie szkutnictwo ludowe XX wieku, (1995), pp. 129-131.

16 Reszka, Wiślane statki, p. 78. 
zwykle wykonywano to na wiosnę. Dopiero po zmontowaniu burt do tak zbudowanego kadłuba wkładano wręgi, mocując je zazwyczaj „na kołki”. Po jednym $\mathrm{z}$ boków dennika osadzano po dwie pary wręgów wyciętych $\mathrm{z}$ naturalnie wygiętych krzywulców (kokor), mocując je drewnianymi kołkami $\mathrm{z}$ bretami. Ściśle przylegały one do dna i burt, gdyż miały na celu wzmocnić wiązanie i usztywnienie kadłuba. Miejsca styku klepek poszycia, denników i wręgów smołowano na gorąco. Szczeliny uszczelniano (dychtowano) parafinowanym bądź smołowanym targanem lnianym lub konopnym, po czym zalewano je gorącym pakiem. Smołowano też burty od linii wodnej pustego kadłuba do maksymalnego zanurzenia przy pełnym ładunku (wolna burta), jako najbardziej narażonej na gnicie z powodu zmian zanurzenia podczas eksploatacji ${ }^{17}$.

Osprzęt bata opisany przez Adama Reszkę ( $\mathrm{z}$ uwzględnieniem lokalnej terminologii, w której dominują germanizmy, będącej „naleciałościami” z czasów zaborów) stanowiły: maszt, dwa żagle (duży i mały), sztanga (rozprza), jechbum (tyczka do rozpinania małego żagla) oraz kilka lin. Maszt swą wysokością przekraczał często $20 \mathrm{~m}$ i był osadzony w specjalnym urządzeniu, szersztoku (także szarsztok), utrzymującym go w pozycji pionowej, oraz wspierany przez zycemla (staropolski sztembloch), ławę drewnianą opartą na górnych krawędziach obu burt, podmasztową ławę denną z gniazdem na stopę masztu (szpur) przymocowanej kołkami do zoli, a także ustawionych w pionie dwóch grubych desek, kleszczy, łączących zycemel z ławą denną. Deski te ustawione równolegle do osi kadłuba zapobiegały wychylaniu się masztu na boki. Wychylenie do przodu uniemożliwiał zycemel, do tyłu natomiast szpantał, czyli forsztag, lina szpanująca, czyli spinająca dziób z wierzchołkiem masztu. Dodatkowe zabezpieczenie stanowił wkładany w szersztok drewniany klocek, fyś czyli „rybka”. Dzięki temu urządzeniu maszty na batach można było łatwo położyć przed przepływaniem pod mostami, a także podczas płynięcia samospławem, zwłaszcza pod wiatr oraz podczas różnych napraw takielunku w razie konieczności odchylenia masztu do tyłu. Maszt stawiano i kładziono przez napinanie bądź luzowanie szpantału na ołubce - prymitywnej windzie ręcznej z poziomym wrzecionem do nawijania liny, umieszczonej w dziobowej części bata między burtami. Winda ta była rodzajem kołowrotu, obracanego ośmioma hand-

17 Ibidem, pp. 78-79. 
szpakami, czyli żerdziami osadzonymi po cztery po obu stronach wijadła ${ }^{18}$. Maszty na batach sporządzano najczęściej z drewna świerkowego, gdyż były lżejsze od masztów sosnowych.

Duży żagiel w kształcie prostokąta stawiano na maszcie i sztandze

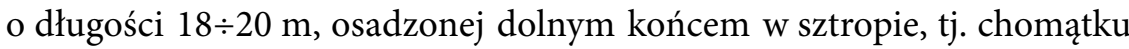
splecionym $\mathrm{z}$ linek stalowych, umocowanym do pnia masztu na wysokości ca 1,5 m nad zycemlem. Kąt nachylenia sztangi regulowano reperem (pikfałem), liną przebiegającą od topu (wierzchołka) masztu, przez blok na wierzchołku sztangi, przez następny blok pod topem masztu, obłożoną końcem na naglu (ruchomym kołku wetkniętym w kwerloch), przewiercony pionowo otwór w betingu na zycemlu. Za pomocą repera można było refować, czyli zmniejszać powierzchnię żagla przy nagłych uderzeniach wiatru lub w sytuacjach nawigacyjnych wymagających spowolnienia ruchu łodzi. Duży żagiel stawiano używając dwóch lin: hycliny (czyli fału grota), idącego od jednego, górnego cypla (rogu żagla), przez blok pod topem masztu do nagla na zycemlu, oraz sznurliny (czyli achterfału), prowadzonego od drugiego, górnego rogu żagla przez blok na noku (górnym końcu) sztangi, do knagi na jej podstawie. Górny róg żagla przesuwał się po maszcie na raksie $\mathrm{z}$ raksklotami (drewnianymi koralikami), a bandowana, czyli obszyta podwójnym pasem płótna żaglowego i obligowana ${ }^{19}$. Mały żagiel (bękart) miał kształt niemal kwadratowy i był podnoszony przed masztem fałem (cwetecajch) prowadzonym od górnego rogu żagla przez bloczek linowy pod topem masztu i obłożony końcem na knadze mocowanej w dole kolumny masztu. Do rozpięcia tego żagla stosowano żerdź (jechbum) mocowaną jednym końcem w dolnej części kolumny masztu za pomocą haka i sztropu. Na drugim końcu tej żerdzi mocowano dolny róg żagla małym achterfałem (małą sznurliną), prowadzoną od tego rogu żagla przez bloczek na noku żerdzi (jechbum), do knagi na przymasztowym końcu żerdzi. Pozostałe dwa "tylne” rogi żagla spinano małym szotem (mała szera), przechodzącym przez bloczek z małą talią (mały szercajch), mocowanym podobnie jak szercajch duży do knagi po wewnętrznej stronie burty. Żagle na baty szyto z brytów jednometrowej szerokości. Dla bata o długości 25 metrów na duży żagiel zużywano 10 brytów o długości pionowej od 13 do 15 metrów, co dawało powierzchnię od 130 do $150 \mathrm{~m}^{2}$. Na mały żagiel

\footnotetext{
18 Ibidem, pp. 80-82.

19 Ibidem.
} 
brano zwykle 8 brytów po 8 metrów długości i uzyskiwano powierzchnię około $64 \mathrm{~m}^{2}$. W sumie ożaglowanie przeciętnego bata mogło przekraczać nawet $200 \mathrm{~m}^{220}$.

Kotwice na batach umieszczano w pozycji wiszącej na bokszprycu (mocnej żerdzi umocowanej do prawej burty przy sztabie). Do boku bokszpryca mocowano blok kotwiczny. Czterołapową kotwicę podwieszano za jedną łapę na boberlinie (bubelajna, zdzierka), mocowanej od łapy kotwicy i biegnącej przez blok na bokszprycu do ołubki, na której wrzeciono nawinięta była boberlina ${ }^{21}$.

\section{WYDOBYWANIE ŻWIRU}

Baty w okolicach Czerwińska i Wyszogrodu budowano zazwyczaj na zamówienie, które najczęściej składali żwirnicy pracujący w okolicach Czerwińska i transportujący urobek pod żaglami z reguły do Warszawy ${ }^{22}$. Mniejsze baty wykorzystywane były do transportu towarów pomiędzy miastami, a także do przewozu pasażerów. W zależności od miejsca zalegania ławic żwiru, do których piaskarze zamierzali dopłynąć, praca trwała dzień (jeśli było blisko, np. piaskarze warszawscy) lub nawet potrzebne były trzy dni, aby dwaj bagrownicy (na przykład z Czerwińska) mogli napełnić kruszywem swoją stosunkowo dużą łódź typu bat. Do miejsc obfitujących w żwir dopływano na wiosłach lub pod żaglami, zrzucano kotwice i rozpoczynano wydobywanie. W tym celu piaskarze zwykle $\mathrm{z}$ jednej strony kadłuba opuszczali tyczki z kaszorami do dna i aby podnieść po zaczerpnięciu pełen czerpak żwiru stawali bosymi nogami na burcie i ciągnęli drąg przechylając się ku wnętrzu łodzi. Wspomagając się ciężarem ciała można było podnieść nad powierzchnię wody urobek w kaszorze. Nie był to koniec cyklu pracy, gdyż $\mathrm{w}$ celu wypłukania $\mathrm{z}$ czerpaka piasku i mułu parokrotnie zanurzano $\mathrm{w}$ rzece i ponownie wynurzano kaszor, tak by pozostawał w nim jedynie żwir. Każdorazowe opieranie drąga $\mathrm{z}$ ciężkim, wypełnionym urobkiem $\mathrm{z}$ wodą o burtę powodowałoby jej niszczenie, dlatego w celu jej ochrony nabijano na krawędź klepki listwę, opaskę podwyższającą także burtę, co w pewnym

\footnotetext{
20 Ibidem, pp. 81-82

21 Ibidem, p. 83.

22 Ibidem, pp. 75-77.
} 
stopniu poprawiało bezpieczeństwo „po brzegi” załadowanej żwirem łodzi. Po wypłukaniu z czerpaka piasku i mułu żwir wysypywano do wnętrza łodzi. Stopniowo wysączała się z niego woda, która wobec przechyłu kadłuba spowodowanego pracą piaskarzy gromadziła się po jednej burcie w jego najniżej położonej części (gratyna), skąd była usuwana za butę drewnianą szuflą. Po uzyskaniu pełnego ładunku załoga prowiantowała się i gotowa do drogi czekała na sprzyjający wiatr. Żegluga żwirnicza batami polegała na wykorzystaniu siły wiatru do żeglugi w górę rzeki („pod wodę”) z ładunkiem, lub spływania z nurtem („Z wodą”), gdy powracano pustą łodzią. W okresach długotrwałego braku wiatru do kursu w górę rzeki korzystano z usług holowników parowych, czepiając się „ogona” pociągu holowniczego. Odcinek drogi w ryzie do Warszawy wahał się od 40 do $110 \mathrm{~km}$ w jedną stronę, a ponieważ najbliższe od Warszawy miejsce eksploatacji kruszywa znajdowało się w Zakroczymiu (km 555), a najdalsze w Dobrzykowie (km 622), z uwagi na ograniczone możliwości holowników największe szanse na podholowanie mieli żwirnicy z najbardziej oddalonych miejscowości, jak Dobrzyków czy Kościelna Kępa (obecnie Kępa Polska, km 606) ${ }^{23}$. Wypełnionym żwirem batem ruszano w górę Wisły, jeśli siła i kierunek wiatru umożliwiały żeglugę. Bat z pełnym ładunkiem swobodnie płynął już pod wiatrem o sile $3^{\circ} \mathrm{B}$. Optymalna dla bezpiecznej i szybkiej żeglugi siła wiatru wynosiła $4 \div 5^{\circ} \mathrm{B}^{24}$. Najbardziej korzystny był wiatr zachodni lub północno-zachodni. Kierunki zbliżone utrudniały żeglugę, a przeciwne uniemożliwiały. Przy wiatrach średnich lub słabych wykorzystywano pełne ożaglowanie, natomiast przy wiatrach silniejszych poprzestawano na dużym żaglu, często zrefowanym za pomocą repera ${ }^{25}$.

Podczas rejsu do Warszawy załogi zmuszone były do dwukrotnego opuszczania masztów: pod mostem w Kazuniu i pod Mostem Gdańskim w Warszawie. Przy ostrym wietrze sprawnie opuszczano maszt „w cugu” (w ruchu), a następnie po przejściu pod mostem szybko go podnoszono. Przy słabym wietrze pod Mostem Gdańskim w Warszawie korzystano często $\mathrm{z}$ tak zwanych wołów, grupy bezrobotnych mężczyzn czekających na okazję odpłatnego przeholowania załadowanego żwirem bata ${ }^{26}$. Ryza do

\footnotetext{
23 Ibidem, pp. 85-87.

24 Ibidem, p. 85.

25 Ibidem.

26 Ibidem.
} 
Warszawy, na którą trzeba było zazwyczaj dwóch dni, z braku sprzyjającego wiatru mogła się przedłużyć do dni kilkunastu. Zdarzało się niekiedy przebyć 65-kilometrową odległość z Czerwińska do Warszawy w jeden dzień, ale to stanowiło wyjątek. Powrót samospławem z Warszawy do Czerwińska trwał $\mathrm{z}$ reguły dwa dni ${ }^{27}$. Załogę bata stanowiło najczęściej dwóch lub trzech ludzi. Byli to: szyper (z patentem) i dorosły pomocnik z praktyką wodniacką pełniący funkcję bosmana oraz niekiedy młodociany chłopiec, traktowany jako uczeń-junga. W wielu wypadkach załogę bata tworzyła rodzina szypra-właściciela: ojciec, matka i kilkoro dzieci. Wszyscy załoganci doskonale znali swe rzemiosło i często w przypadkach szczególnych, przy zdekompletowanej obsadzie, w pojedynkę obsługiwali baty w czasie żeglugi. Przykładowo żona pewnego szypra podczas jego nieobecności wykorzystując sprzyjający wiatr, przy pomocy dwojga nieletnich dzieci doprowadziła załadowany żwirem, uprzednio przygotowany do podróży bat z Wyszogrodu do Warszawy, dopilnowała wyładunku i pomierzenia żwiru, pobrała zapłatę, a następnie wróciła do Wyszogrodu samospławem ${ }^{28}$.

\section{ŁODZIE PIASKARSKIE Z JAROSŁAWIA}

W latach 1978-1988, kiedy prowadziłem badania polskiego szkutnictwa ludowego, moją uwagę zwróciły konstrukcje pływające, które wykorzystywano na Sanie już tylko do rekreacji, a zwłaszcza do wędkarstwa. Przed laty takie łodzie używano do wyławiania żwiru ${ }^{29}$. W znikomej już liczbie (i to tylko w Jarosławiu) udokumentowałem pod koniec lat 70. stosunkowo małe łodzie, które niegdyś stosowano na Sanie do wydobywania żwiru z dna rzeki. Już w 1933 roku interesował się nimi Ernest Klein, badacz z Nordiska Museet w Sztokholmie ${ }^{30}$. Było tam wówczas takich konstrukcji znacznie więcej, niż w czasie, kiedy prowadziłem badania. Wykonane przez Kleina zdjęcia są cenne, gdyż ukazane na nich konstrukcje nie różnią się wcale od dokumentowanych przeze mnie niemal pięćdziesiąt lat później. Podczas jego pracy dokumentacyjnej w Jarosławiu łodzie były przede wszystkim używane

\footnotetext{
27 Ibidem, p. 91.

28 Ibidem, pp. 87-88.

29 Litwin, Polskie szkutnictwo ludowe, p. 91.

30 Ibidem, pp. 91-92.
} 
do piaskarstwa. Natomiast kiedy ja je dokumentowałem, żwir wydobywano $\mathrm{z}$ rzeki koparką. Wtedy też tamtejszym łodziom zmieniono przeznaczenie, korzystając z nich do celów rekreacyjnych, głównie do wędkarstwa. Udokumentowane $\mathrm{w}$ Jarosławiu łodzie miały dna składane $\mathrm{z}$ dwóch szerokich albo trzech węższych klepek i były lekko wygięte na długości. Jednopasowe burty nieznacznie rozchylono na zewnątrz, a od strony dolnej miały nieco wysunięte poza płaszczyznę dna krawędzie. U większości z nich połączenie klepek z deską przodu miało dwustopniowy wpust i dzięki temu kadłub był odpowiednio wzmocniony. Zakończenia łodzi były płaskie i stosunkowo grube.Ze względu na tradycyjne przeznaczenie - wydobywanie z nich i przewożenie żwiru - miały mocne usztywnienia poprzeczne. W środku była ładownia ograniczona dwiema grodziami. Na ich górnych krawędziach znajdowały się ławki. Pomiędzy nimi mocowano składane bocznie dwie lub trzy pary wręgów wykonanych z naturalnie wyrośniętych krzywulców. W przedniej części kadłuba osadzano najczęściej jedną parę wręgów, natomiast w tylnej, jak widać to na fotografii wykonanej przez Kleina, była dawniej jedna gródź sięgająca połowy wysokości burty, z ułożoną na niej ławeczką. Podczas prac w Jarosławiu stwierdziłem w niektórych łodziach brak takiego siedziska i zastąpienie grodzi listwą pełniącą funkcję dennika. Łodzie w Jarosławiu były uszczelniane podobnie, jak łodzie rybackie konstruowane $\mathrm{w}$ tamtym regionie. Wykonywano je z pasm mchu bagiennego wciskanego w szczeliny pomiędzy stykami poszczególnych klepek. Od zewnątrz miejsca te poszerzano wycinając w deskach, płytki, trójkątny w przekroju poprzecznym rowek. Po wciśnięciu w te rowki uszczelnienia przybijano skobelkami listwy dociskające. W tylko jednej z inwentaryzowanych przeze mnie łodzi piaskarskich przetrwała charakterystyczna nakładka: listewka na górnej krawędzi klepki przy grodzi, o którą opierano drąg kaszczora podczas wybierania żwiru z dna rzeki. W czasach, kiedy Klein był nad Sanem, tego rodzaju zabezpieczenia miała większość tamtejszych łodzi. Łodzie piaskarskie napędzano na pych tyczkami albo wiosłami z jesionu z metalowym okuciem końca pióra.

\section{ŁÓDŹ PIASKARSKA - KRYPA EKSPLOATOWANA NA WISŁOCE}

Najliczniej występującymi w 1985 roku łodziami nad Wisłoką, kiedy wykonywałem tam prace inwentaryzacyjne, były konstrukcje zwane krypami. Udokumentowałem je na dolnym biegu Wisłoki w miejscowościach 
Rzędzinowice, Kiełków i Gawłuszowice ${ }^{31}$. Używano ich przede wszystkim do wydobywania żwiru z dna rzeki oraz przewozu na drugi brzeg ludzi i ładunków. Ich długość wynosiła od 7 do 9 m, a szerokość 2,0 do 2,2 m. Krypy piaskarskie miały płaskie dno, były podgięte z przodu i nieznacznie podniesione z tyłu. Burty miały rozchylone na zewnątrz, a klepki ich (dwa pasy) były ułożone na styk. W rzucie poziomym przód kadłuba był węższy, podczas gdy rufę tylko lekko zwężono w stosunku do rozmiaru śródokręcia. Skrajne części łodzi miały swoje nazwy. Sporządzony z belki przód nazywano progiem, a pawęż w rufie zatyłkiem. Zasadniczym usztywnieniem poprzecznym kadłuba było dno składające się z wielu klepek przybijanych prostopadle (w poprzek) do burt. Oprócz tego w niektórych łodziach mających dwa lub trzy pasy klepek burtowych zastosowano usztywnienia w charakterze bocznych wręgów nazywane subkami. Były nimi listwy przybite pionowo do burt po wewnętrznej stronie kadłuba. Zmiana kierunku przebiegu klepek dna z wzdłużnego na poprzeczny spowodowała konieczność usztywnienia wzdłużnego tej konstrukcji. W tym celu przytwierdzono po wewnętrznej stronie kadłuba jedną lub dwie równoległe deski, biegnące wzdłuż całej łodzi i spinające w ten sposób klepki dna. Element taki nazywano tam wręgiem. Ważną częścią w konstrukcji krypy używanej do wydobywania żwiru były listwy relingowe. Przybijano je do górnych krawędzi klepek burtowych. Chroniły one burty przed uszkodzeniami następującymi podczas opierania o nie nóg piaskarzy, a później trzonów kaszorów, podczas tradycyjnego wydobywania żwiru z dna rzeki. Uszkodzoną, przetartą listwę można było w razie potrzeby wymienić, co było dogodniejsze niż wymienienie całej klepki. Operacja taka mogłaby trwale zdeformować kadłub. Łodzie piaskarskie uszczelniano mchem, konopiami, pakułami, a nawet resztkami tkanin. Szczeliwo takie wtłaczano pomiędzy klepki od zewnątrz kadłuba i dociskano w szczelinach listwami z jałowca (dychami). Mocowano je do klepek poszycia żelaznymi skobelkami. Całą konstrukcję zwykle konserwowano smołą drzewną. Krypy piaskarskie napędzano tyczkami (laskami).

Wytwory szkutnictwa ludowego nad Wisłoką reprezentują grupę łodzi o unikatowych rozwiązaniach konstrukcji dna montowanego z poprzecznie układanych desek. Rozwiązania tego rodzaju są niezwykle rzadko stosowane w Europie, mają jednak ciekawe analogie na obszarach zamieszkałych

\footnotetext{
31 Ibidem, pp. 79-82.
} 
przez ludność słowiańską. Łodzie o tak montowanym dnie w kilku wariantach konstruowane są nad jeziorami kaszubskimi, a także na Łużycach, na rozlewiskach Szprewy. Nazewnictwo typów łodzi znad Wisłoki - krypa i galarek - ma też analogie w terminologii wodniackiej dorzecza Wisły. Dowodzi to trwałości od dawna wypracowanych kontaktów żeglugowych, czyli spławu do Wisły. Gdy taka forma żeglugi zamarła stosowane już tylko lokalnie łodzie poddano modyfikacji technicznej, której założenia najprawdopodobniej powstały nad tą rzeką. Tam też zapewne innowacja ta utrzymywała się dłużej, gdyż łodziami nie podróżuje się już poza ten region. Zanikło też piaskarstwo łodziowe. Dlatego uważam, że nie doczekają się one dalszych transformacji. Krypy i inne łodzie na Wisłoce są obecnie już rzadkością.

\section{KRYPY PIASKARSKIE W SZCZUCINIE}

W 1983 roku na odcinku Wisły pomiędzy ujściem Dunajca (Ujście Jezuickie) i Szczucinem kontynuowałem dokumentowanie tradycyjnych łodzi. Rezultatem było między innymi zinwentaryzowanie ostatnich w Polsce krypek piaskarskich śrutówek ${ }^{32}$. Trzy takie jednostki eksploatowano w Szczucinie, dwie w Ujściu Jezuickim. W rzucie poziomym miały one kształt prostokątny, od przodu dno ich było podgięte ku górze. Przód (próg) wykonany był z belki, rufa (zatyłek lub cal) złożona była z kilku desek. Burty (dwu lub trójpasowe) składane były na styk oraz uszczelniane mchem dociskanym listwami mocowanymi żelaznymi skoblami. Usztywnieniami poprzecznymi były denniki (progi) oraz wręgi wspierające burty (bręgi). Podobnie nazywał części swojej krypki przewoźnik z Opatowa, przewożący przez Wisłę w Ujściu Jezuickim.

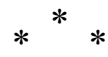

Powyższa prezentacja łodzi piaskarskich oparta została w dużej części na publikacji Adama Reszki i dotyczy bata, największej łodzi stosowanej dawniej w wiślanym piaskarstwie. Konstrukcji takich już się nie spotyka

32 Ibidem, p.160. 
na Wiśle. Pozostałe przykłady form szkutniczych udało mi się udokumentować w latach 80. XX wieku, zapewne w ostatnich latach ich eksploatacji. Szkoda, że podobnych badań nie prowadzono na większą skalę wcześniej. Zapewne udałoby się wówczas ustalić również inne regiony, gdzie wydobywano żwir, składowano oraz transportowano w nieznanych nam już dzisiaj typach łodzi.

\section{PIASKARZE NA WIŚLE I ICH ŁODZIE (XIX-XX WIEK)}

\section{STRESZCZENIE}

Jednym z zajęć nadrzecznej ludności w XIX i XX wieku było wydobywanie żwiru i piasku z dna rzeki. Do wykonywania tej pracy posługiwano się rożnego typu łodziami i prostymi narzędziami (kaszczorami). Dużym ośrodkiem piaskarstwa wiślanego był odcinek rzeki pomiędzy Warszawą i Czerwińskiem. Zajęcie to zanikło w połowie XX wieku.

\section{SANDGEWINNUNG (SANDGEWINNER*) AN DER WEICHSEL UND DIE DAFÜR EINGESETZTEN BOOTE (19.-20. JAHRHUNDERT)}

ZUSAMMENFASSUNG

Eine der möglichen Beschäftigungen der an den Flüssen wohnenden Bevölkerung im 19. und 20. Jahrhundert war die Gewinnung von Kies und Sand vom Boden des Flusses. Für diese Arbeit wurden verschiedene Bootstypen und einfache Werkzeuge verwendet (kaszczor). Ein großes Zentrum für Sandgewinnung an der Weichsel war ein Flussabschnitt zwischen Warschau und Czerwińsk. Diese Beschäftigungsart verschwand in der Mitte des 20. Jahrhunderts.

Übersetzt von Renata Skowrońska

\section{VISTULIAN DREDGERS AND THEIR BOATS $\left(19^{\mathrm{TH}}-20^{\mathrm{TH}}\right.$ CENTURY $)$}

\section{SUMMARY}

One of the activities of the riverside population in the $19^{\text {th }}$ and $20^{\text {th }}$ centuries was the extraction of gravel and sand from the bottom of the river. To perform this work, various types of boats and simple tools (e.g. kaszczor) were used. A large

\footnotetext{
* Polnisch piaskarze - Bezeichnung für Personen, die bei der Kies- und Sandgewinnung gearbeitet haben.
} 
centre of the Vistulian dredgers was a section of the river between Warsaw and Czerwińsk. The profession became extinct in the mid-20 $0^{\text {th }}$ century.

Translated by Anna Maleszka

\section{SŁOWA KLUCZOWE / SCHLAGWORTE / KEYWORDS}

- Wisła; San; Wisłoka; piaskarze; łodzie

- Weichsel; Saan; Wisłoka; Sandgewinnung (Sandgewinner); Boote

- the Vistula; the San; the Wisłoka; dredgers; boats

\section{BIBLIOGRAFIA / BIBLIOGRAFIE / BIBLIOGRAPHY}

\section{LITERATURA / LITERATUR / LITERATURE}

Boczar M., Galeona Zygmunta Augusta. Próba rekonstrukcji, (1973).

Kleczkowski A., Rejestr budowy galeony. Zabytek z r. 1572, (1915).

Litwin J., Polskie szkutnictwo ludowe XX wieku, (1995).

Łuczyński E., Staropolskie słownictwo związane z żegluga. XV i XVI wiek, (1986).

Reszka A. W., Wiślane statki i techniki nawigacyjne od XVI do XX wieku, (2012).

Ślaski B., Rybołówstwo i rybołówce na Wiśle dawniej i dziś, (1917).

Ślaski B., Spław i spławnicy na Wiśle, (1916). 


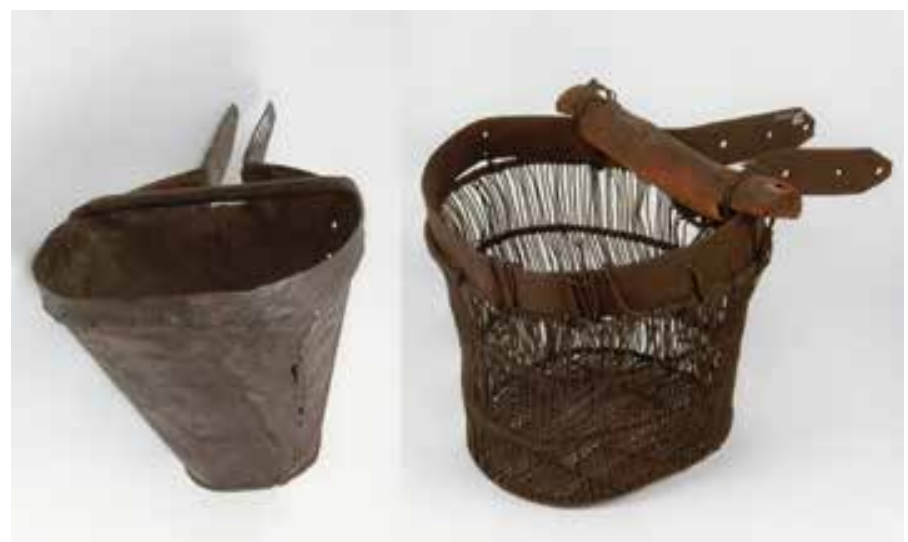

1. Kaszczory, metalowy i druciany, używane przez nadwiślańskich piaskarzy. Ze zbiorów Narodowego Muzeum Morskiego w Gdańsku. Fotografia: Narodowe Muzeum Morskie w Gdańsku

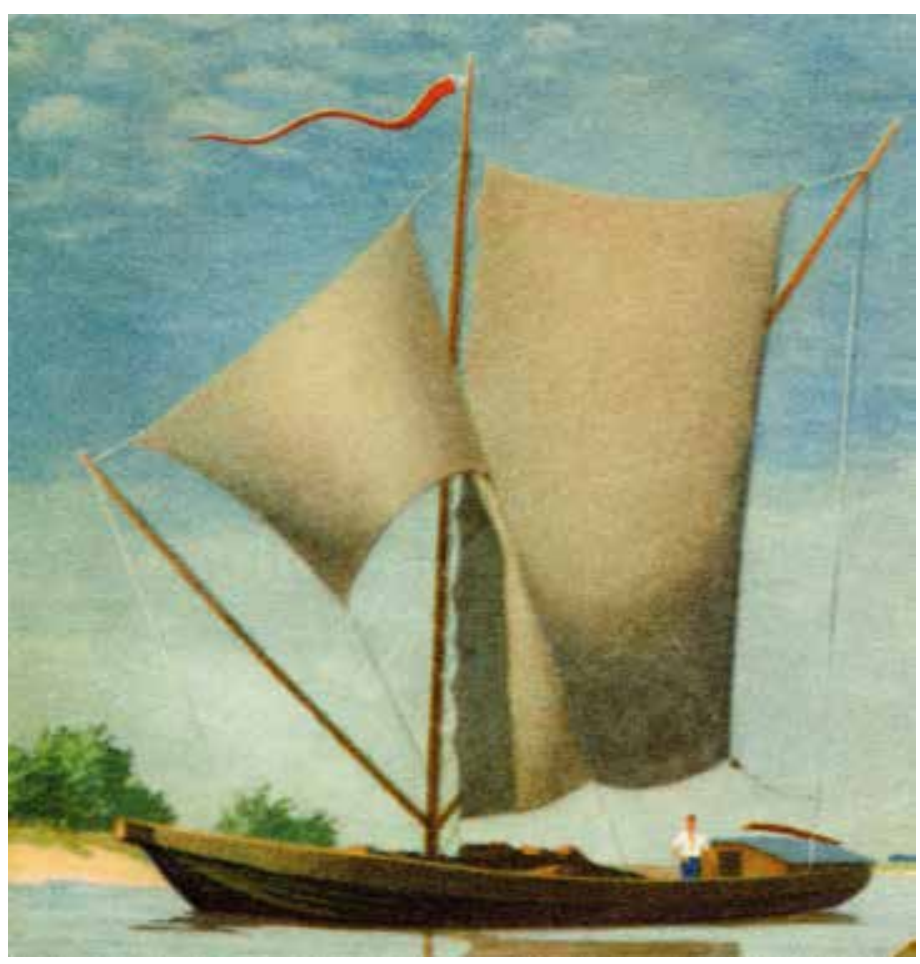

2. Akwarela Janusza Reszki Bat pod żaglami (1954 r.). Reprodukcja w zbiorach Narodowego Muzeum Morskiego w Gdańsku. Fotografia: Narodowe Muzeum Morskie w Gdańsku 


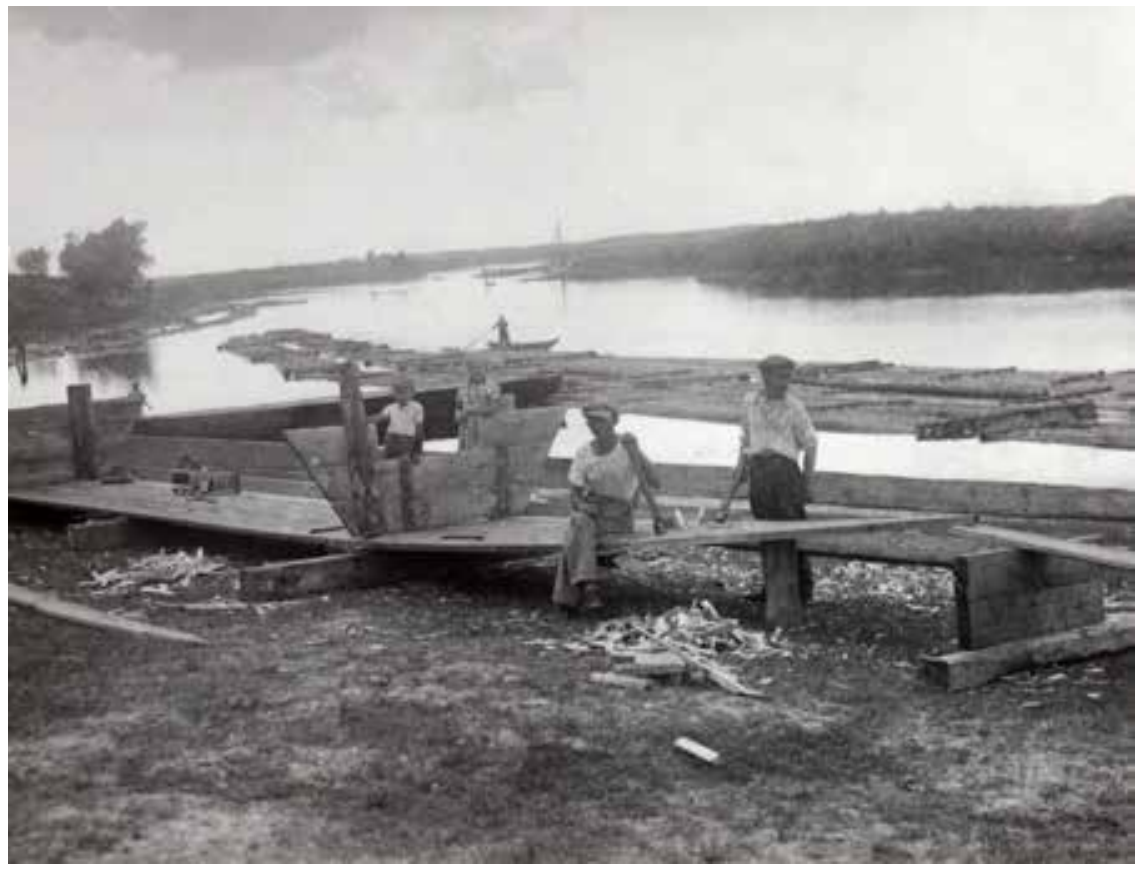

3. Budowa bata w Nowogrodzie nad Narwią (1947 r.). Fotografia ze zbiorów Muzeum Archeologiczno-Etnograficznego w Łodzi

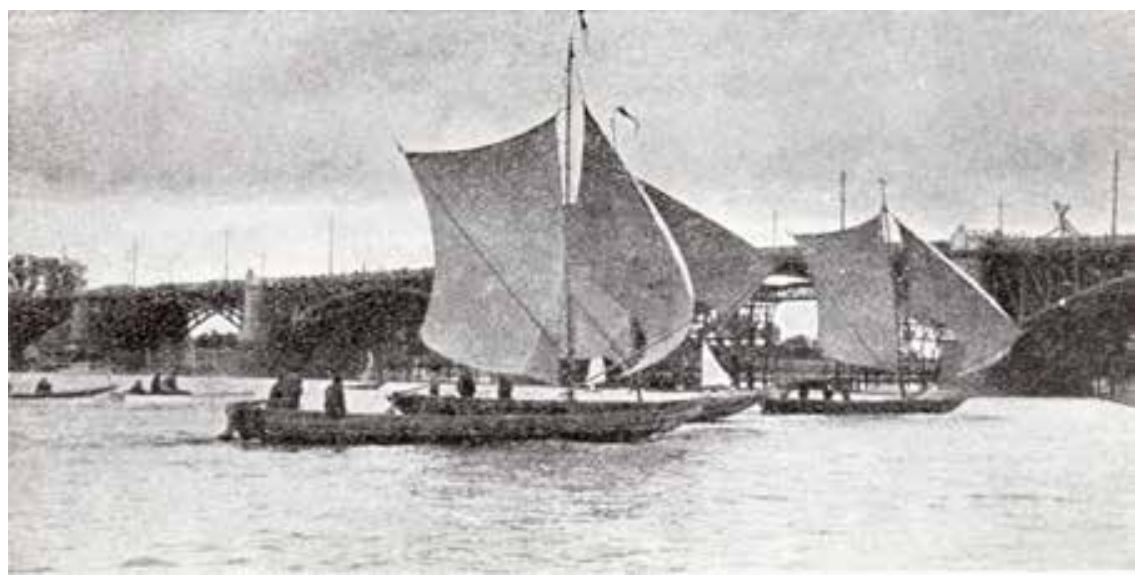

4. Archiwalna fotografia dokumentująca regaty batów piaskarskich na Wiśle w Warszawie (lata 30. XX w.) 


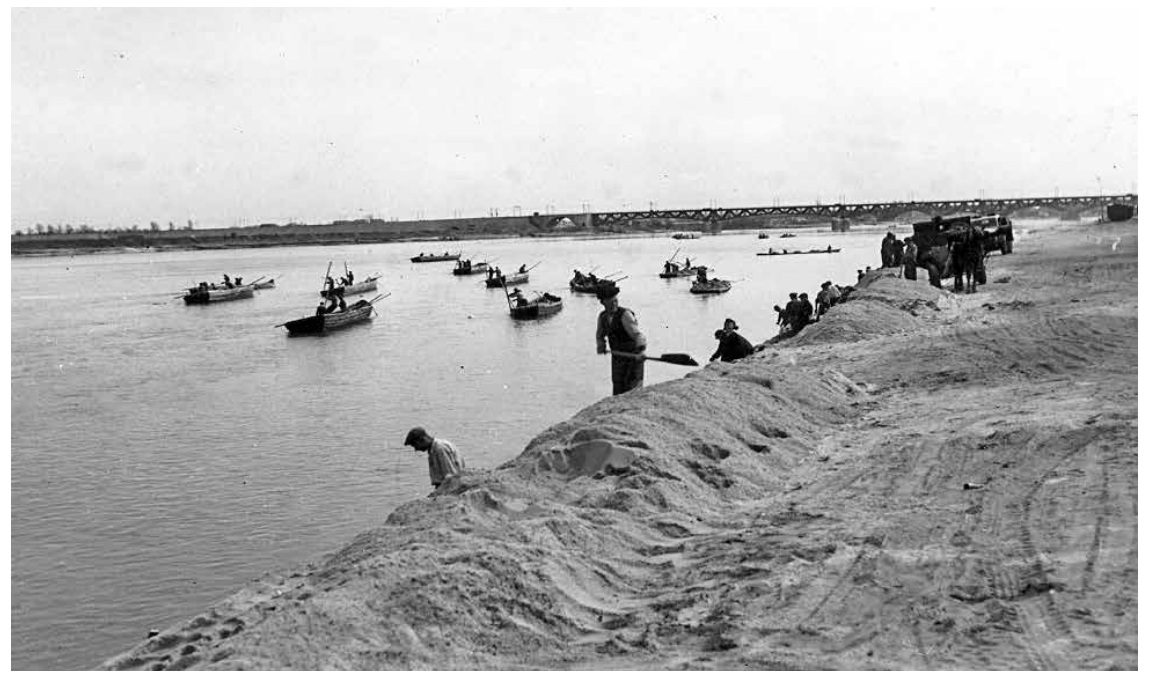

5. Wyładownia piasku $513 \mathrm{~km}$ Wisły (obrzeża Warszawy), w nurcie rzeki małe łodzie piaskarskie (fot. ze zbiorów A. Reszki)

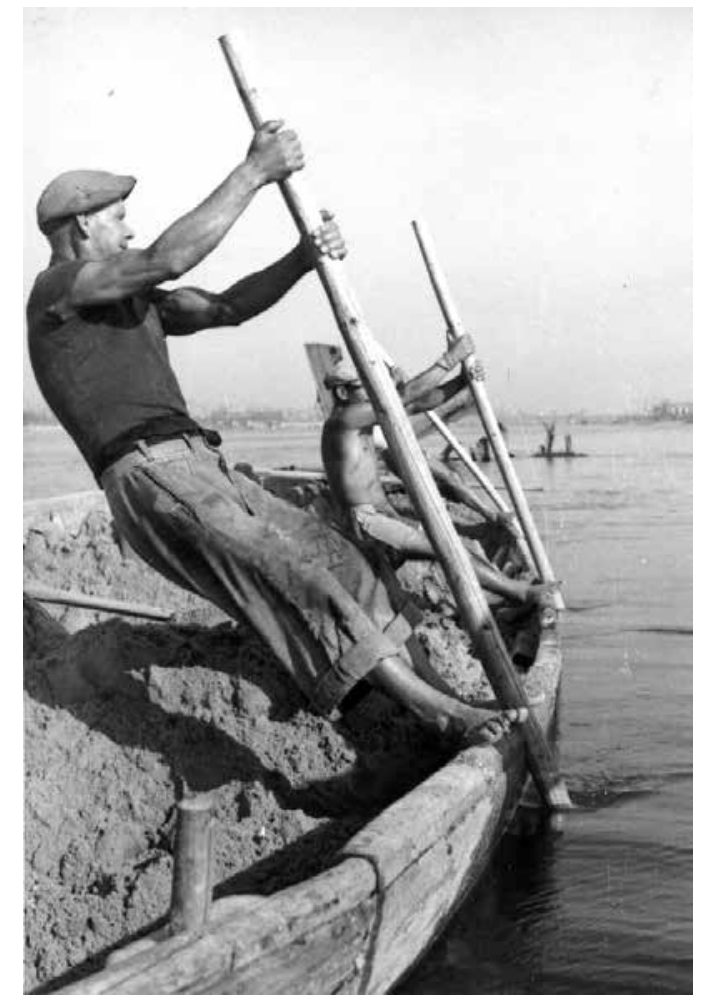

6. Wydobywanie żwiru do bata na Wiśle (fot. ze zbiorów A. Reszki) 


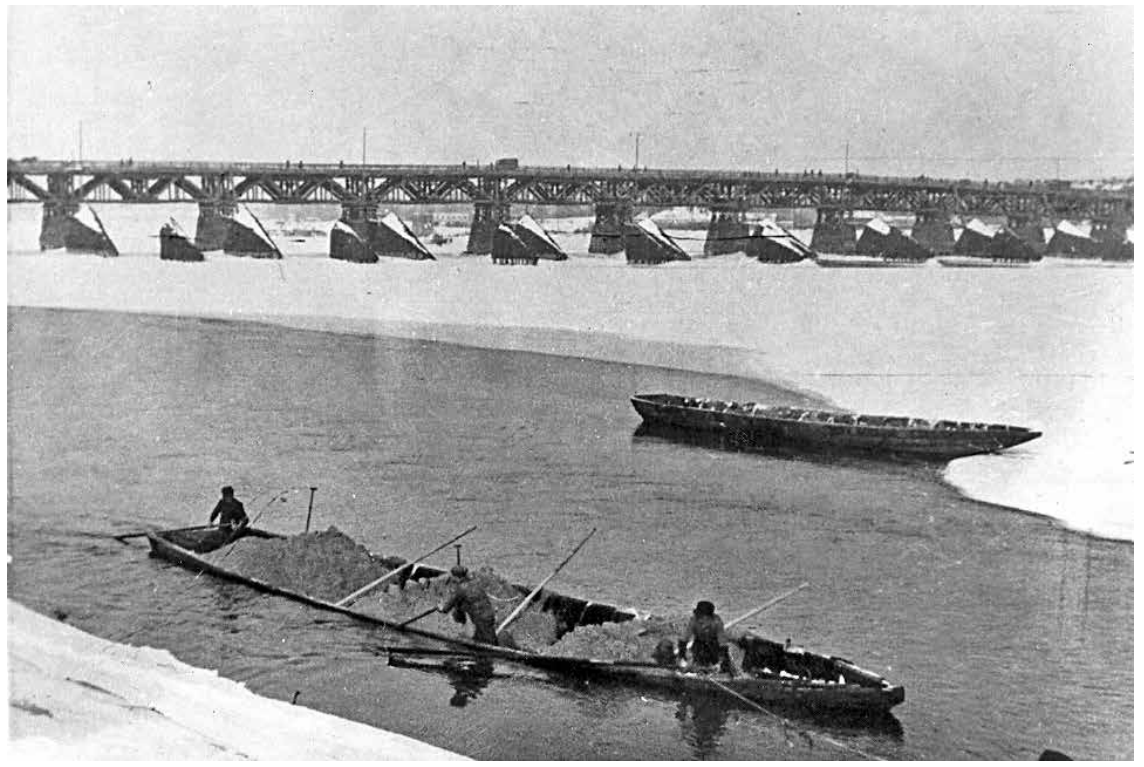

7. Na Wiśle jeszcze utrzymywały się lody, kiedy do pracy przystępowali piaskarze, na zdjęciu bat maksymalnie załadowany holowany do wyładowni w Warszawie (fot. ze zbiorów A. Reszki)

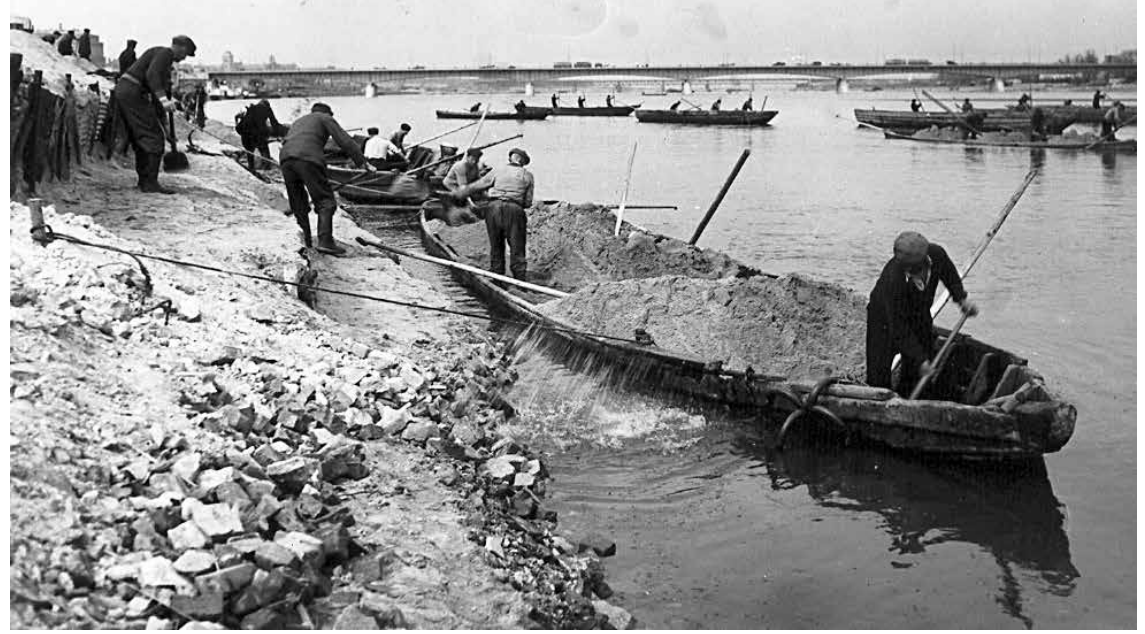

8. Przygotowania do wyładunku żwiru, na drugim planie baty piaskarzy na stanowisku wydobywczym (fot. ze zbiorów A. Reszki) 


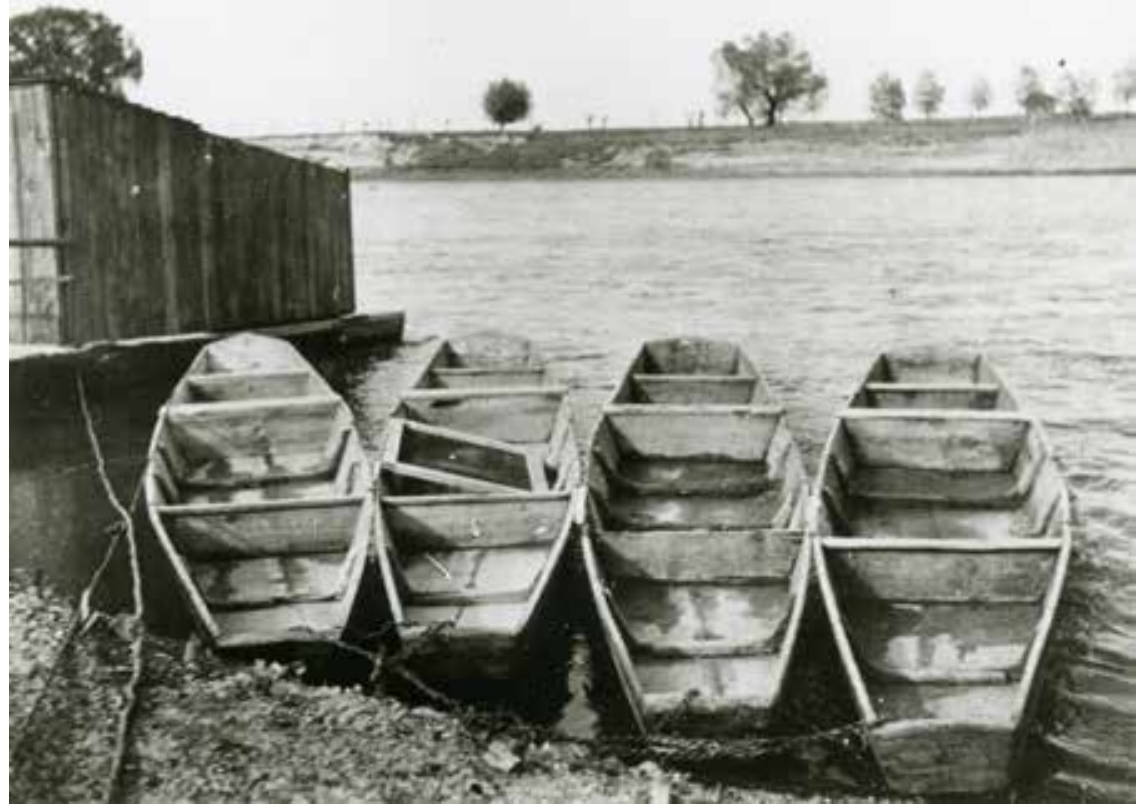

9. Łodzie piaskarskie udokumentowane w 1933 roku na Sanie w Jarosławiu przez E. Kleina (fot. w zbiorach autora)

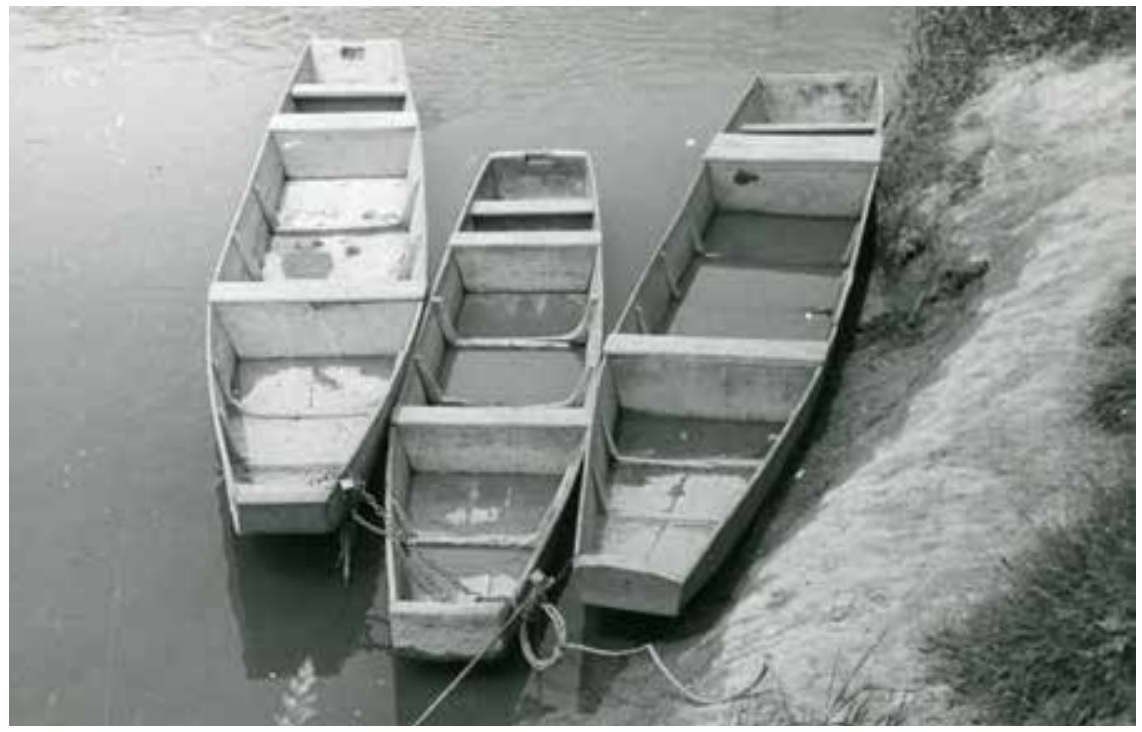

10. Łodzie w Jarosławiu udokumentowane przez Autora u schyłku lat 70. XX w. 

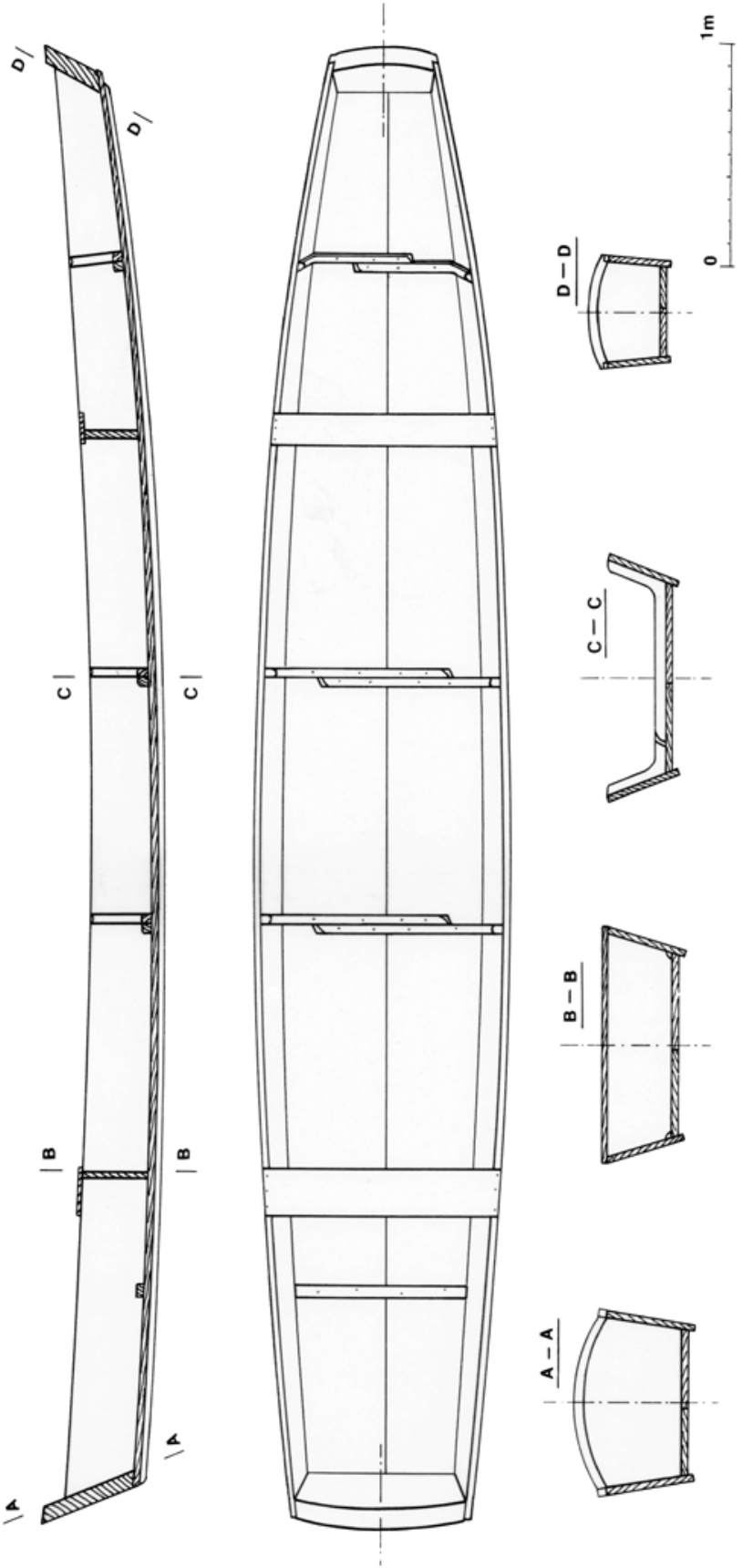

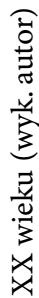

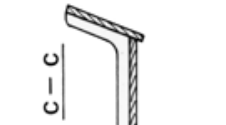

0

촐

产
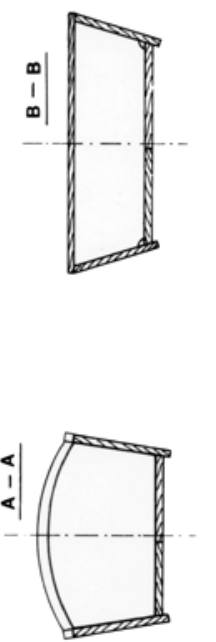

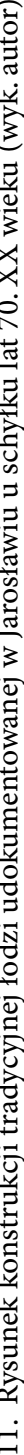




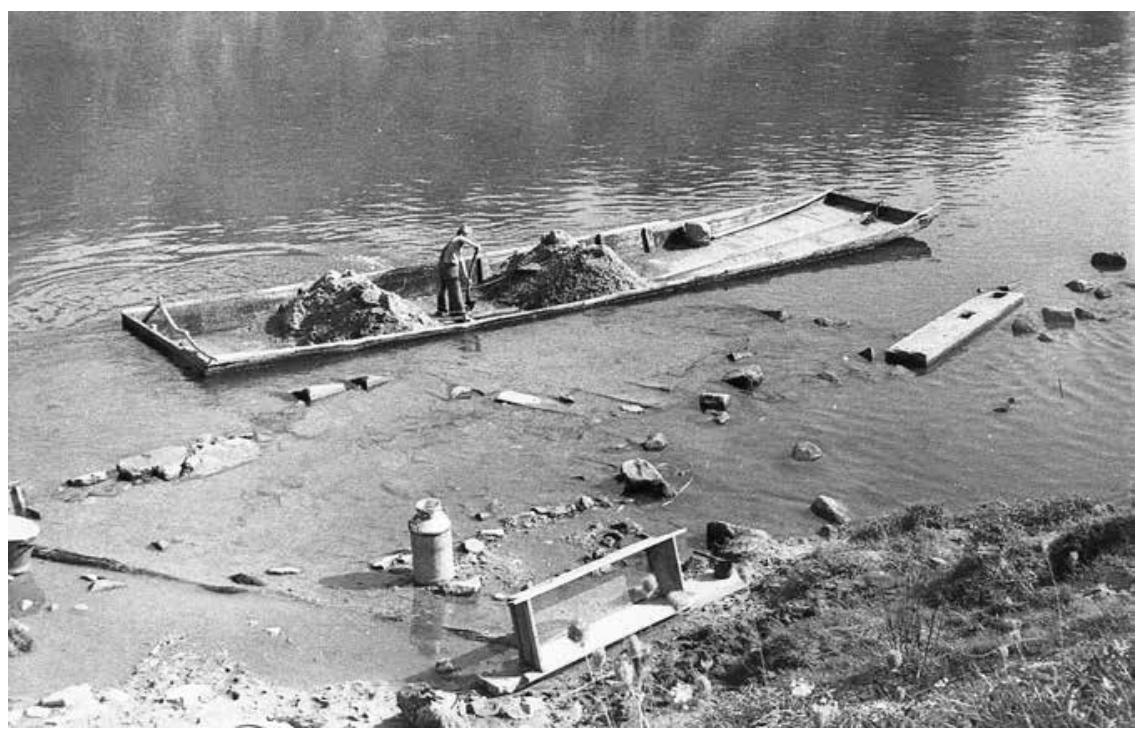

12. Łódź piaskarska na Wisłoce we wsi Kiełków, usuwanie wody wysączającej się ze żwiru, schyłek lat 70. XX wieku (fot. autora)

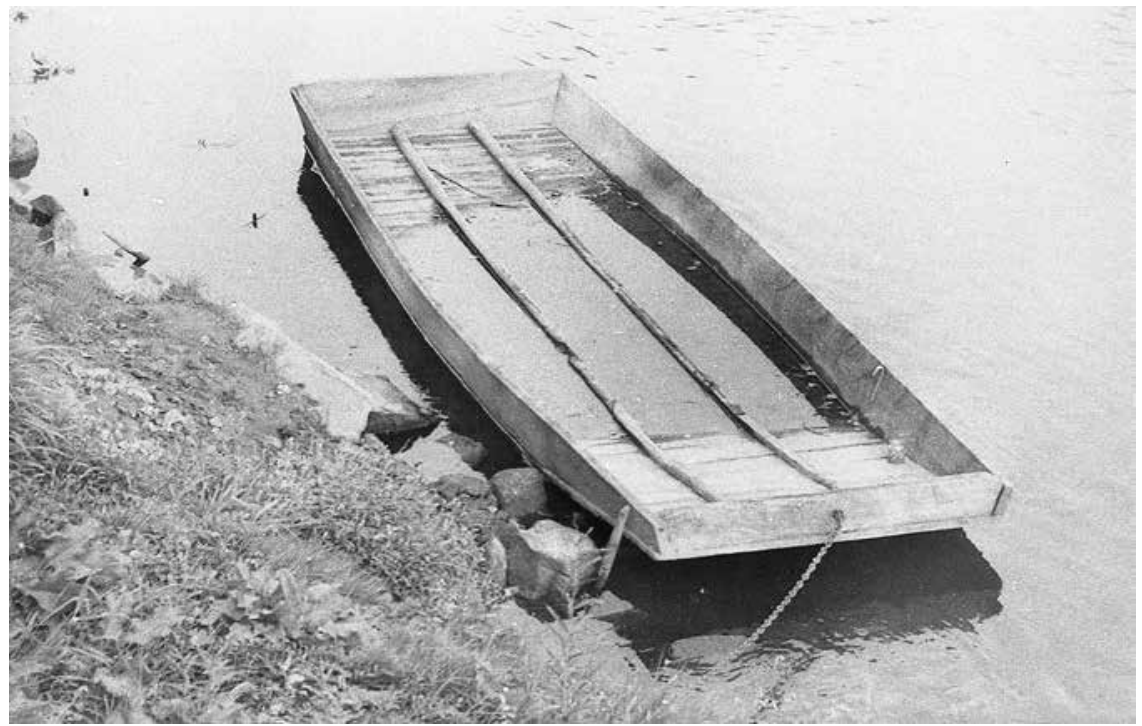

13. Łódź piaskarska na Wisłoce we wsi Kiełków, widoczna charakterystyczna konstrukcja dna, schyłek lat 70. XX wieku (fot. autora) 
A

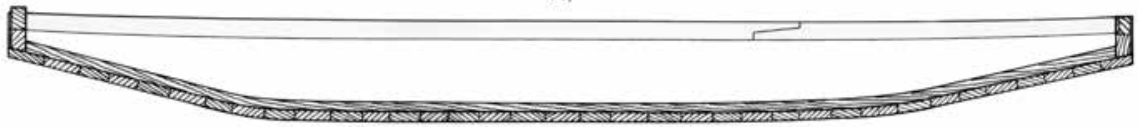

Al
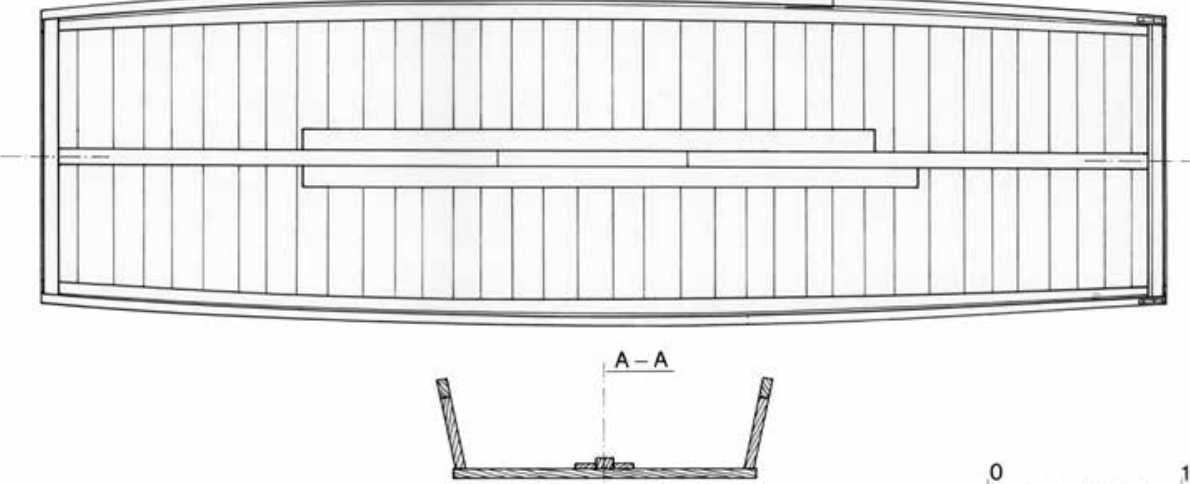

0 $1 \mathrm{~m}$

14. Rysunek konstrukcji tradycyjnej łodzi piaskarskiej udokumentowanej w Kiełkowie nad Wisłoką (wyk. autor)

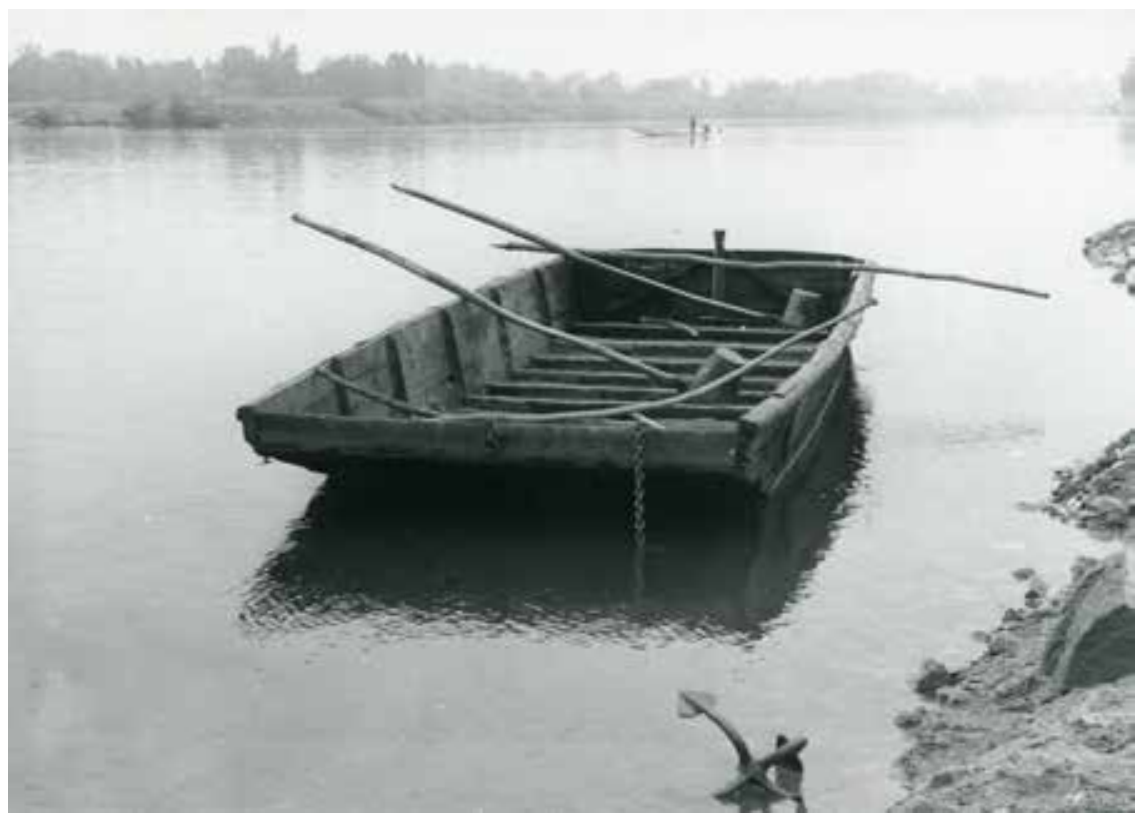

15. Łódź piaskarska ze sprzętem do wydobywania żwiru na Wiśle w Szczucinie, schyłek lat 70. XX wieku (fot. autora) 


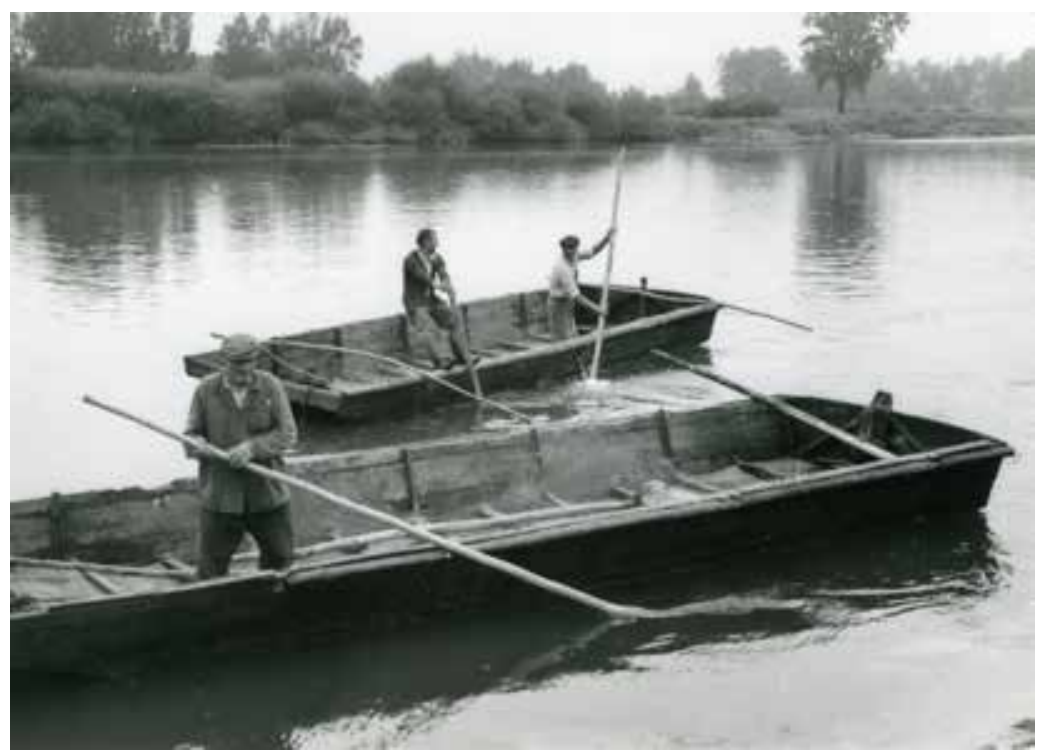

16. Wydobywanie żwiru, Szczucin, schyłek lat 70. XX wieku (fot. autora)

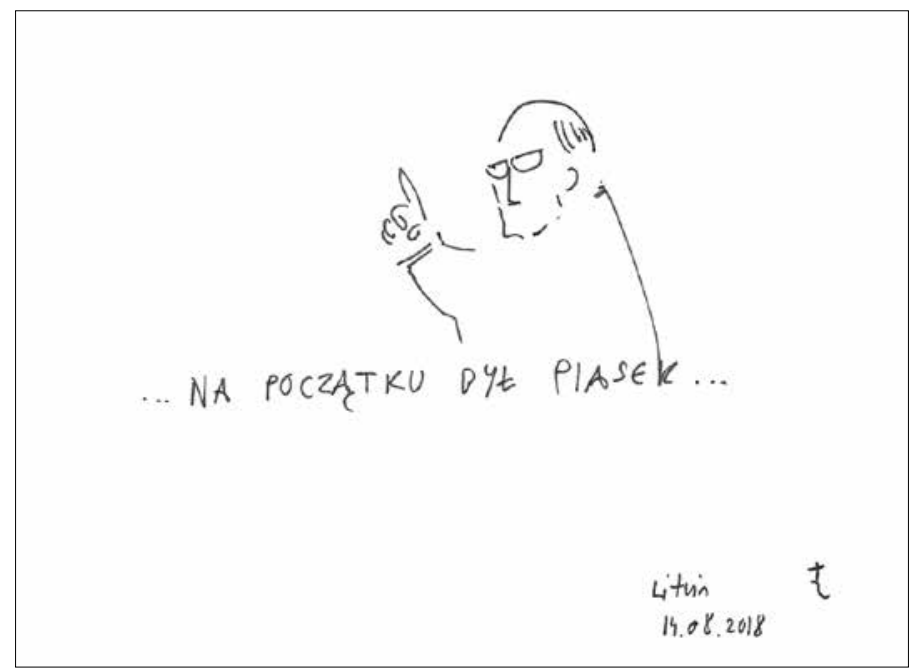

$17 \mathrm{a}$

17a-d. Ilustracje wykonane podczas referatu Jerzego Litwina (14 sierpnia 2018 r.), rys. Bogusław Małusecki 
[249]

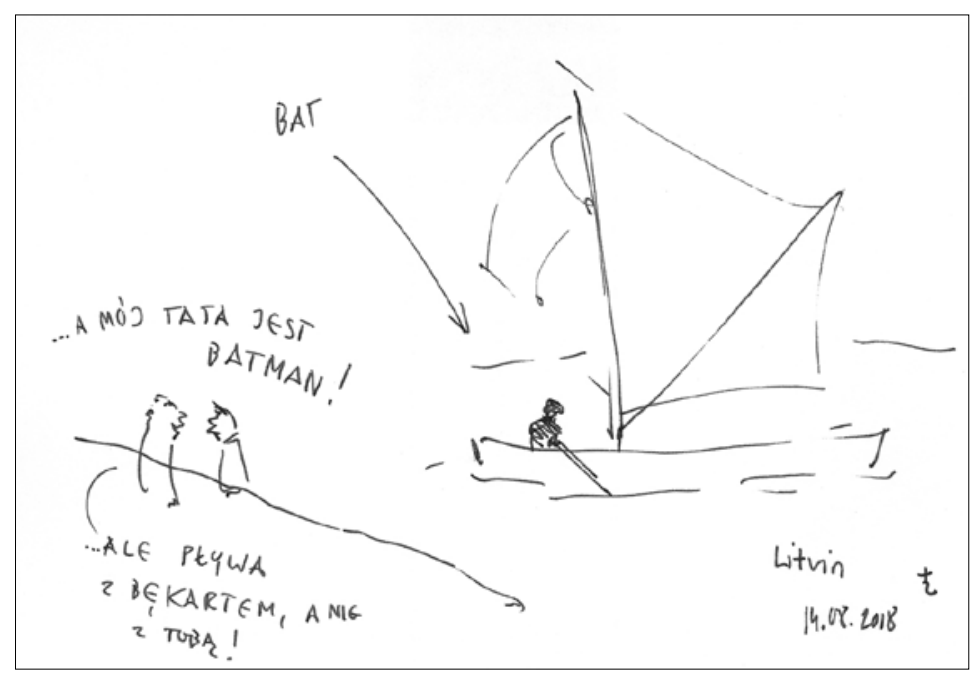

$17 b$

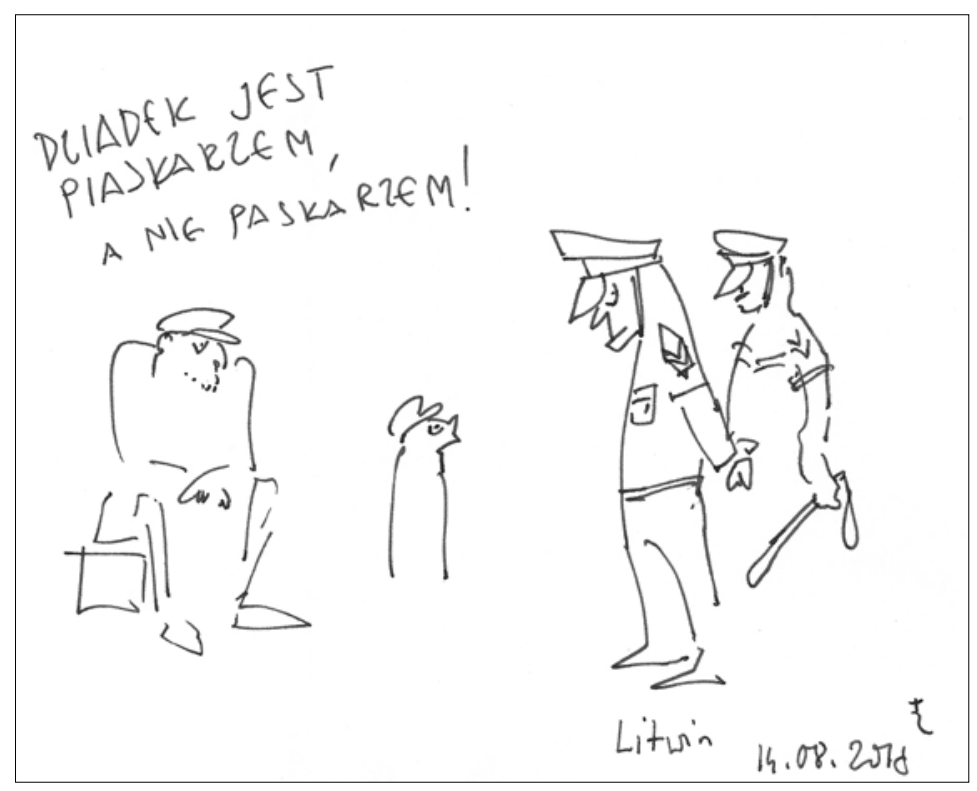

$17 \mathrm{c}$ 
[250]

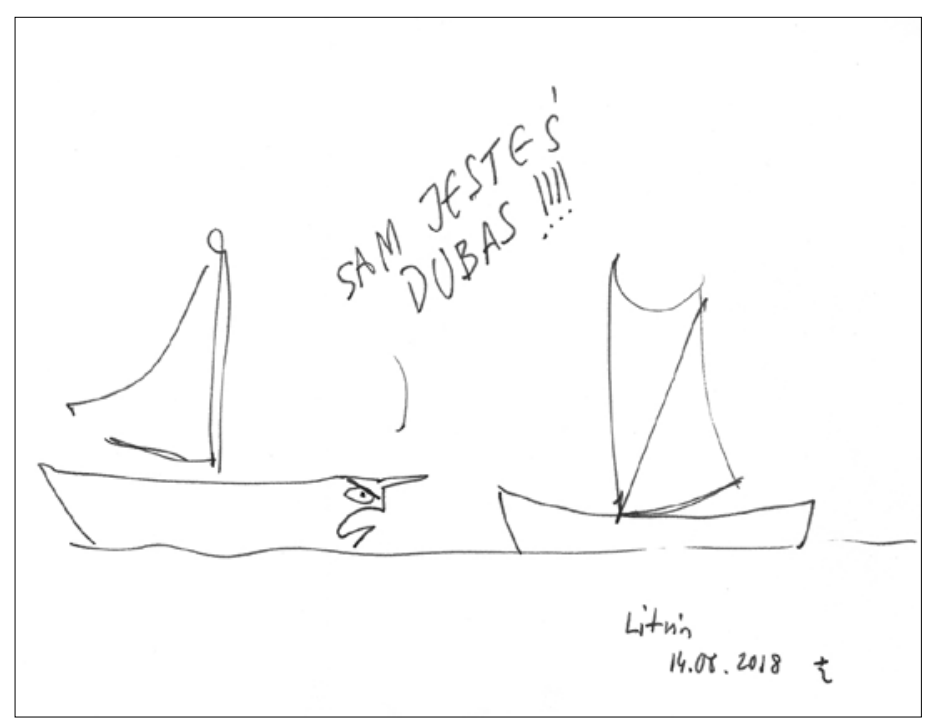

$17 d$ 